\title{
AZ INKLUZÍV NEVELÉS ÉS A DEBRECENI TANÁRKÉPZÉS
}

\section{Petö ILdikó}

\author{
a Debreceni Egyetem Neveléstudományok Intézetének \\ egyetemi adjunktusa \\ petoildiko@arts.unideb.hu
}

\begin{abstract}
Az együttnevelés (integráció, inklúzió) már a jelen pedagógiai gyakorlata, amit vagy jól, vagy kevésbé jól, de naponta végeznek a pedagógusok. Ahhoz, hogy a pedagógusképzés képes legyen lépést tartani az állandóan változó igényekkel, azzal, hogy a pedagógusok napról napra többet (de úgy érzik, hogy nem eleget) tudnak a sajátos nevelési igényü tanulók oktatásáról, maguknak a képzö intézményeknek, az oktatóknak is változniuk kell. Meg kell keresniük azokat az elemeket, amelyeket beépithetnek azokba az ismeretanyagokba, amelyeket eddig esetleg nem érintett az együttnevelés jelensége.
\end{abstract}

Napjainkban már nem csak a kihívást kereső, vállalkozó szellemü pedagógusok kerülnek együttnevelési helyzetbe, hanem bárki találkozhat az osztályában SNI tanulóval. Ezzel együtt megnőtt a módszertani, óravezetési és nevelési felelősség is, de újabb feladatok is megjelentek a napi munkában. De az is nyilvánvaló, hogy a pedagógusok nem tudnak, vagy csak nehezen tudnak segítséget kérni, esetleg nem is tudják, honnan kaphatnának iránymutatást az új feladatukhoz.

Az utóbbi évek gyors változása miatt a hagyományos osztályok tanárai elbizonytalanodtak saját pedagógusszerepükben, kérdések fogalmazódnak meg bennük. Ráadásul sok esetben az inkluzív oktatás bevezetése úgy történik, hogy a tanárok, akik valójában főszereplők az együttnevelésben, az ezt célzó politikák megvalósításában, nem ismerik az inklúzió lényegét és céljait (Goodfellow, 1990), s csak egy „felülröl” jövő nyomásnak engedve végzik.

A változás látványos, még akkor is, ha az együttnevelést oktatáspolitikai szinten alternatívaként ajánló törvény ${ }^{1}$, amely nagy hatással volt például az új Országos Fogyatékosügyi Program ${ }^{2}$ végrehajtásának 2007-2010 évekre vonatkozó középtávú intézkedési tervre is, lassan már húsz éves. A Program három pontban tér ki a pedagógusképzésre:

- Bővíteni kell a sajátos nevelési igényủ tanulókat befogadó közoktatási intézmények körét, biztosítva az egyéni tanulási igényekhez jobban alkal-

\footnotetext{
1 Az 1993. évi LXXIX. Törvény a közoktatásról

2 1062/2007. (VIII. 7.) Korm. határozat az új Országos Fogyatékosügyi Program végrehajtásának 20072010. évekre vonatkozó középtávú intézkedési tervéröl; www.szmm.gov.hu/openlink.php?linkID=1263
} 
mazkodó módszerek alkalmazását. A gyógypedagógiai nevelésben-oktatásban részt vevő iskolákat fel kell készíteni a sajátos nevelési igényü gyermekek oktatásával kapcsolatos módszertani feladatok ellátására.

- Az oktatás valamennyi szintjén a tanulók életkori sajátosságainak megfelelő tananyagok összeállításával kell lehetővé tenni a fogyatékosságokról szóló ismeretek elsajátítását.

- A tanító- és tanárképző intézményekben elérhetővé kell tenni az integrált oktatási formák, a fogyatékos gyermekekkel való kommunikációs és oktatási módszerek elsajátításának lehetőségét.

A középtávú intézkedési terv részletesen és kiemelten foglalkozik az oktatás (át)alakításával és a pedagógusok felkészítésével, amibe hosszú távon a felsősoktatást is beleérti két okból is. Részben, mert az attitüdformálásban és a fogyatékos tanulók iskolai sikerességében a pedagógusoknak van kulcsszerepe, részben pedig, mert a fogyatékosok magasabb iskolai végzettsége, piacképes képzettségük az önellátásukat, önálló életvitelüket segítené. Javítaná azt az általános helyzetet, hogy a fogyatékosok és a fogyatékos gyermekek családjai mélyen a társadalmi átlag alatti színvonalon élnek, folyamatos az elszegényedésük. A Program határozottan és világosan fogalmaz azzal kapcsolatban is, hogy mit várnak el a pedagógusképző intézményektől és a pedagógus-továbbképzéseket szervezőktől: tartalmi, tartalomszerkezeti és módszertani megújulást. Nemcsak azt a változást nehéz elindítani, hogy a különböző képzések egységesek és kiegyensúlyozottak legyenek, de a megfelelö út és az arányok megtalálása is sok kérdést vet fel egy olyan országban, ahol a pedagógusképzésben is szegregációs hagyományokat követnek.

\section{Az inkluzív oktatás és pedagógusképzési programtípusok}

A fogyatékosok inkluzív oktatásával kapcsolatos nemzetközi összehasonlításban, bár nagyon színes a kép a pedagógusképzés filozófiáját, szerkezetét és tartalmát tekintve, két modell karakteresen elkülöníthető egymástól: az egyik a „hagyományos" (tanegység alapú), a másik pedig az a típus, amelyben a fogyatékosokkal, az oktatásukkal és az ellátásukkal kapcsolatos ismeretek minden tantárgyba beépülnek egy-egy részlethez kapcsolódva. Az utóbbi modellt az angol nyelvü szakirodalom „content infusion” néven vezette be (Forlin et al., 2007), magyarul a lényegét talán a „tartalombővíto"” modell elnevezés fejezi ki.

A tanegységben (tantárgyi rendszerben) gondolkodó „hagyományos modell” néhány (esetenként egy) tantárgyba süríti azokat a szükségesnek vélt, a különbözö tudományterületekhez tartozó ismereteket, amelyeket fontosnak tart az eltérö fejlödésű tanulókkal kapcsolatban. Ebben az esetben szisztematikusan, külön gondolatmenetként dolgozható fel a tantervalapú értékelés, képességfejlesztés, kooperatív tanulás, differenciált tanulásszervezés és -irányítás, a fogyatékosságok kórtana és 
jellemzői, az SNI gyerekek oktatásának céljai, a stigmatizáció, a megfelelő terminológiák, az inkluzív nevelés, a vonatkozó oktatáspolitika értelmezése, és az együttnevelést támogató részeinek az elemzése.

Mindez történhet nagy létszámú előadás formájában, esetleg a tanterem falain belül maradó szemináriumok (gyakorlat) formájában, amelyek során csak az oktató az ismeretközlő. A „hagyományos modell” azonban szervezhető úgyis, hogy egyben saját élményt és praktikumot is biztosítson a hallgatók számára. Meg lehet hívni olyan vendégelőadókat, akik maguk is fogyatékosok, vagy fogyatékos gyerekekkel foglalkoznak szegregált formában vagy inkluzívan, esetleg fogyatékos gyermek szülöje. Olyan környezetben (intézményben, szervezetnél) kell a hallgatóknak bizonyos időt eltölteni, ahol fogyatékosok élnek, például szabadidős programot szerveznek és vesznek részt azokon. A tanóra keretében látogatást lehet szervezni szegregált, de még inkább együttnevelést folytató iskolába. A témával foglalkozó filmet lehet közösen megnézni, blogokat, egyéb internetes oldalakat megismerni, kiadványokat összegyüjteni és bemutatni. Az oktatás és az azt körülvevő társadalom szoros kapcsolatának az érzékeltetésére felkérhető a település egy vezetője, aki bemutatja a helyi települési programot, segít annak értelmezésében, a befolyásoló tényezők, a prioritások megértését. Feladatként kiadható prezentáció, újságkészítés, poszterkészítés és -bemutató, vizsgálat elvégzése, projekt munka, valamilyen „akcióterv" készítése, amelyben a lehetőségekhez képest fogyatékos személy is részt vesz, aminek a során a hallgatóknak célzott, képességet fejlesztö kis csoportban (is) kell dolgozniuk.

Sok szerző szerint a „tartalombővíto” modell („contant infusion”) az egyszeri hatással, azaz a hagyományos tanegységes formával szemben, sokkal inkább segíti az inkluzív nevelés elfogadását (Cook, 2002). Ebben a formában a fogyatékos emberekre vonatkozó ismereteket szisztematikusan, a képzés minden elemébe beépítik a képzés teljes egésze során. Azaz nem kínál kurzusokat kifejezetten az inkluzív oktatás vagy a fogyatékosságok témájában, hanem minden tantárgy érinti ezt a szempontot úgy, hogy bemutatja az együttnevelés filozófiáját és gyakorlatát, valamint a társadalmi hátrányos helyzetet. A modell filozófiája szociális konstruktivista megközelítésü, s azt feltételezi, hogy ha minden tanegység foglalkozik a témával, akkor ki lehet alakítani a társadalmi egység érzését és a komplex gondolkodást, a reflektív habitust, természetessé válik a saját értelmezésen alapuló vélemény kialakítása. Külön hangsúlyt kaphat a saját élményủ tanulás, ami tanulási folyamatként és a tanulás eredményeként (például mint alkalmazandó módszer) is értelmezhető a pedagógusképzésben $\mathrm{E}$ megközelítésben a különböző természet- és társadalomtudományos tantárgyak tanításának ,,módszertanában” kifejezetten nevesített oktatási cél a differenciált óravezetés és a többféle alternatív értékelés megismertetése.

A hallgatók a különböző kurzusok során gyakorlati feladatokat kaphatnak, amelyek közül szinte „kötelező”, hogy például egyéni fejlesztési tervet állítanak össze, differenciált óratervet, esetleg esettanulmányt készítenek egyénileg vagy cso- 
portban. A hallgatói feladatok természetesen a „tartalombővítő” modell esetében is változatosak, sokszínủek lehetnek, kiléphetnek a tanterem falai közül, megismertethetnek a helyi viszonyokkal, s kapcsolatot alakíthatnak ki saját tapasztalatot biztosítva a fogyatékos gyerekek, fiatalok, felnőttek, családjaik és a velük foglalkozó különböző szakemberekkel.

A kétféle képzési modell és ezek kombinációi felkeltették a szakemberek érdeklődését, s megindultak a hatékonyságvizsgálatok, amelyek továbbra is megosztják a programok tervezőit. Az újabb modell („tartalombővítő” modell) mellett érvelök, például Ellen M. Kowalski (1995) véleménye szerint a fogyatékosságokkal kapcsolatos ismereteknek a hagyományos ,szóló” kurzus során való megszerzése esetén, a pedagógusok hamarabb és gyorsabban alkottak negatív, lemondó véleményt az SNI diákokról. Úgy érezték, hogy a fogyatékos tanítványaik magányosabbak az iskolában az alacsonyabb szintü szociális képességeik és kompetenciáik miatt. A „tartalombővítő" modell támogatóinak meggyőződése az, hogy a pedagógusjelöltek folyamatosan olyan kihívásokkal találkoznak a képzés során mind a fogyatékosokkal kapcsolatos ismereteik asszimilálásában, mind pedig ezen tudásuk alkalmazásában, aminek eredményeképpen az elkötelezettségi szintjük emelkedik.

Az új utat keresőket azonban elbizonytalaníthatja néhány közelmúltbeli kutatás, miszerint a „tartalombővítö" modell nem olyan hatékony, mint azt eleinte feltételezték a szakértők. Akasmit és Alcorn (1988; In: Sharma et al., 2008) elemezte és értékelte az USA-ban a szövetségi támogatásból kidolgozott és bevezetett „Mainstream Curriculum Infusion Model"-t. A vizsgálat tapasztalatai szerint, a tanárok, akiket „tartalombővítő” programmal képeztek, úgy érezték, hogy a kapott ismeretek nem elég konkrétak, ezért nehezen alkalmazhatóak a gyakorlatban konkrét helyzetekben, tehát megszerzett tudásuk az együttneveléssel kapcsolatban nem kielégítő. Egy másik tanulmány a „tartalombővíto”” modell kapcsán (Cook, 2002) hasonló eredményeket közölt, miszerint a pedagógusjelöltek véleménye és motiváltsága az inklúzióval kapcsolatban a képzés hatására nem javult jelentősen.

Azonban mindkét irányzat képviselői megegyeznek két dologban. Az egyik, hogy a tanárjelölteknek legyen lehetöségük arra, hogy minél több alkalommal, helyzetben és módon tudjanak beszélni aggodalmaikról, félelmeikröl azzal kapcsolatban, hogy a végzés után egy együttnevelést hirdető iskolában, egy inkluzív osztályban kell majd dolgozniuk. A tapasztalatok alapján kialakult másik fontos közös pont: azok a pedagógushallgatók, akik közvetlen és közvetett módon rendszeresen kapcsolatba kerültek fogyatékos személyekkel, egyértelmủen úgy érezték, hogy jobban megértik és felismerik a fogyatékosok életének különböző akadályait, tájékozottabbakká váltak a helyi, inklúziót támogató oktatáspolitikában és törvényhozásban is. Mindezek pedig idővel, közvetve formálják az inklúzióval kapcsolatos pozitívabb oktatási és szociális attitüdöt. 


\section{Az inkluzív oktatás dilemmái a pedagógusképzésben}

A szakmai diskurzusok és vizsgálatok napjainkban egyre inkább az együttneveléssel kapcsolatos tartalmi kérdésekkel kell, hogy foglalkozzanak, aminek kettős oka van. Az egyik, hogy a következő pedagógusgeneráció tagjait olyan kompetenciákkal, tudással, képességekkel, attitüdökkel kell kiengedni a képző intézményekből, amelyek már alkalmassá teszik őket az együttneveléssel kapcsolatos mindennapi problémák kezelésére, így például képesek lesznek a differenciált tanulásszervezés eredményes megszervezésére, megvalósítására. A másik indok, hogy gondolkodni és gondoskodni kell a már pályán lévők továbbképzésről. A gyakorlattal rendelkezők felkészitése a sikeres együttnevelésre nem azonos a pályára készülőkével, hiszen esetükben egy már meglévő tudást, szokásrendszert, rutint és attitüdöt kell új elemekkel dúsítani, átalakítani és fejleszteni.

A pályán lévők tudására, képességeire, attitüdjeire alapozni kell, s részben helyzetük, munkakörük, feladataik szerint ráépíteni az elvárt, a szükséges kompetenciákat. Mindeközben arról sem lehet elfeledkezni, hogy jelentős az eltérés az inkluzív gyakorlatok elfogadottságában egy országon belül területenként és településtípusonként is. A vidéki tanároktól is azt várják, hogy feleljenek meg az együttnevelés kívánalmainak, miközben kevesebb segítséget és támogatást kapnak, mint a nagyobb városok iskoláiban dolgozó kollégáik, hiszen a távolság miatt a tanácsadó és a segítő szolgáltatások a távoli területek iskolái és pedagógusai számára alig-alig hozzáférhetőek. De az is tudott a kisebb településeken dolgozó pedagógusokkal kapcsolatban, hogy az együttnevelés meghirdetése előtt is szívesen fogadtak az osztályukba fogyatékos tanulót, valószínüleg a kistelepülések szorosabb emberi kapcsolatai miatt (Fields, 1993; Petó és Nagy, 2004a, 2004b).

Egyértelmü, hogy a pedagógusképző intézményeknek is reagálniuk kellett a már nem csak kihívás szintjén lévő elvárásokra. A bolognai szerkezet részben meghatározta a kereteket, de a tartalmat semmiképpen sem. Az elvárásoknak való megfelelés a képzőktől is új ismereteket, sőt teljes megújulást kívánt, de az utóbbi, hazánk hagyományai miatt csak részben következett be.

A módszer és gondolkodásmód váltása, az új ismeretek elsajátítása, az attitüdváltás nem csak a gyakorló pedagógusok körében jelenti a hatékonyság gátját, de a pedagógusképzők oktatóinak a körében is, pedig a pedagógusképzésben résztvevőnek, az oktatóknak és a gyakorló tanításokat vezetőknek a felelőssége hatványozott. Ha visszautalunk a fentebb írtakra, miszerint az általános fogyatékossági ismereteken túl biztos módszertani kompetenciák szükségesek a sikeres együttneveléshez, akkor nem kétséges, hogy a módszertanokat oktatók és a tanítási gyakorlatot vezetők kulcspozícióban vannak. De ezzel együtt azt is be kell látnunk, hogy a képzőintézmények ilyen módon érintett szakemberei azok, akik még nem, vagy csak kevesen gondolták újra tevékenységüket, amin nem is lehet csodálkozni, hiszen a témához eddig nem volt közük. Belátható, hogy a pedagógusképzők oktatóinak szervezett és 
célirányos felkészítése nélkül nem várható el ezektől a szakemberektől, hogy felkészültek és motiváltak legyenek a munkájuk átalakítására. A gyakorló iskolák többségében nem tanulnak SNI tanulók, így tantermi keretek között sem láthatnak mintát a különböző helyzetekre a pedagógushallgatók, ráadásul sem elméleti szinten, sem a gyakorlatban nem képezi a „tananyag” részét sem a differenciált óravezetés előkészítéseként a differenciált óratervezet készítése, sem az egyéni fejlesztési terv összeállítása.

\section{A Debreceni Egyetem tanárképzésének ,inklúziós” elemei}

A Debreceni Egyetemen a tanárképzés új képzési rendszerének indulásakor 2006ban a levelezö tagozaton arra a kérdésre, hogy ki tanított már sajátos nevelési igényü tanulót, csak elvétve, néhányan jelentkeztek, s bizony, amikor elhangzott az, hogy „SNI tanulók”, akkor visszakérdeztek, mi ez, hogyan kell leírni. Mára, néhány évvel az indulás után egy 25 fős, tanárképzésben részt vevő csoportból a többség vagy éppen mindenki, akinek már van tanítási gyakorlata, azt jelezte, hogy az iskolájukban tanul SNI „A” vagy SNI „B” javaslattal érkező diák. Ez a változás, ami a nappali tagozatosokat is jellemzi, kétségtelenül megváltoztatja az együttneveléssel kapcsolatba hozható oktatási célokat, tartalmakat és módszereket, hiszen már nem bevezető ismeretekre van szükségük a hallgatóknak. De a továbblépés egyre szélesebb területeket, egyre több oktatót is érinteni fog (érintenie kellene), hiszen az SNI tanulók a közoktatás teljes skáláján és minden szintjén jelen vannak, s képességeiktől függően helyet követelnek a felsőoktatásban is.

A Debreceni Egyetem több mint 80 éves hagyományokkal rendelkezik a tanárképzés területén. Napjainkban a követelményeknek megfelelően, a bolognai típusú képzési rendszerhez illeszkedik a tanárképzési programja, eddig 19 akkreditált szakon, amivel a közismereti tanárszakok teljes palettáját kínálja (ábrázoló geometria és müszaki rajztanár, angoltanár, biológiatanár, fizikatanár, földrajztanár, franciatanár, hon- és népismeret-tanár, informatikatanár, kémiatanár, könyvtárpedagógia-tanár, környezettan-tanár, latintanár, lengyeltanár, magyartanár, matematikatanár, némettanár, orosztanár, pedagógiatanár, történelemtanár, zenetanár, zenemüvész-tanár). Tanárképzési programját „A tanári mesterszak képzési és kimeneti követelményeit (KKK) tartalmazó leírás (a 15/2006 (IV. 3.) OM rendelet 4. sz. melléklete a 24/2010. (V. 14.) OKM rendelet alapján.)" alapján szervezte meg mind nappali, mind levelezö tagozaton.

A nappali tagozatos hallgatók képzése több tanegységen keresztül részleteiben és önállóan érint(het)i az együttnevelés problémakörét. A kötelező pszichológiai és pedagógiai tárgyak többsége (valójában mindegyike) alkalmas arra, hogy az oktatók folyamatosan beépíthessék a vonatkozó ismereteket (A személyiségfejlesztés pedagógiai-pszichológiai alapjai; A tanítási-tanulási folyamat; A nevelés szociálpszichológiája; Iskolai mentálhigiéné, hátrányos helyzet, veszélyeztetettség; Iskolai 
tehetségfejlesztés; A tanulók megismerése és az iskolai teljesítmény; Didaktika; Pedagógiai programfejlesztés; Pedagógiai értékelés).

A választható tárgyak többségéről ugyanez mondható el, ami egységes szemléletet és képzési attitüdöt képviselhet (Modern szemléltetés; A tanulás tanítása; Modern irányzatok a pedagógiában; Nevelésszociológia; Oktatási rendszerek az EUban; A tanári pálya komplex kérdései; Tanári mesterség; Kutatások a nevelésszociológiában; Oktatásstatisztikai elemzések - nemzetközi összehasonlításban -, és a tárgyak adta lehetőségeket nem nehéz felismerni. Például a „Modern szemléltetés" megmutathatja, hogy a különböző sajátos nevelési igényt, hogyan lehet kielégíteni a technika segítségével, s milyen „,veszélyei” lehetnek a technikai eszközöknek, amelyek hosszú távon a tanulási folyamatra és a tanuláshoz szükséges képességekre hatnak. Szerencsés esetben arra is lehetőség nyílhat, hogy például a látássérültek életét segítő újfajta eszközök felhasználásáról is tudást, illetve tapasztalatot szerezhessenek a tanárjelöltek, vagy megismerhessék mi is az az ,indukciós hurok ${ }^{3 ”}$. A „Pedagógiai programfejlesztés” és a „Pedagógiai értékelés” magában rejti azokat az elemeket is, amelyek szükségesek az együttnevelö iskola müködéséhez, az SNI-vel kapcsolatos törvények és rendeletek betartásához. Az „Oktatási rendszerek az EU-ban” címü tárgy rávilágíthat, hogy vannak országok, iskolarendszerek, amelyekben természetes az együttnevelés, és értelmezheti a nemzetközi összehasonlításokban azt, hogy az SNI tanulókkal kapcsolatos adatok miért mutatnak akkora eltérést. „A nevelés szociálpszichológiája" keretein belül lehetőség nyílik, hogy a stigmatizációt, az előítéleteket, az osztálytermi marginalizálódást, vagy éppen az elfogadást értelmezze a fogyatékos és a tanulási zavarral küzdő tanulók helyzetén keresztül is. A tanári pályával és mesterséggel foglalkozó tanórák esetében kikerülhetetlen, hogy a többségi/hagyományos iskolák megszokott pedagógusszerepeinek a változása, értelmezése mellett szóba kerüljön az is, hogy újabb feladatként és felelösségként jelentkezik az SNI tanulókkal való foglalkozás szinte már minden pedagógus és iskola gyakorlatában.

A képzésben résztvevők tartalmi megújulása mellett meghatározó módszertani átalakulás érdekében az oktatók (két fö) bekapcsolódott a Hátrány és Iskola Szakmai Mühely ${ }^{4}$ programcsomagjainak a kipróbálásba (Árnyalt tanulóértékelés; Multikulturális tartalmak - Interkulturális nevelés).

Az együttneveléssel kapcsolatban két önálló választható tanegység („,Tanulási nehézségek” és az „Együttnevelés a közoktatásban”) szerepel a képzésben a választható tárgyak között. A pedagógiai választható tárgyak meghirdetéséről rendszeresen megkérdezik az érintett hallgatókat, amely eljárást lehet (és érdemes) úgy értelmezni, hogy a képzés végéhez, a tanári diploma megszerzéséhez, illetve a szak-

\footnotetext{
${ }^{3}$ A komplex akadálymentesítésben használatos elektronikus eszköz, hangfrekvenciás hurokerősítő rendszer

${ }^{4}$ http://hiszem.hu/hiszem
} 
mához egyre közelebb kerülő jelöltek ilyen módon jelezhetik, hogy hol éreznek hiányosságot a képzésben, kompetenciáikban.

A visszajelzések alapján minden tanév első félévében meghirdetésre került a „Tanulási nehézségek”, amely széles alapról közelít az együttneveléshez és az SNI tanulókhoz. A bevezető témakörök az együttnevelés problémaköre oldaláról értelmezi a már ismert fogalmakat, $\mathrm{s}$ folyamatokat (tanulás; zavar a teljesítményben (teljesítményzavar); alulteljesítés, alulellátottság; a fogalmak összefüggései; szegregáció, integráció, inklúzió; a teljesítményzavar okai: - külső okok, belső okok, fogyatékosság; külső okok által kiváltott zavarok, nehézségek: gyenge tanulók, felszíni/ál tanulási zavarok, leszakadók, szakiskolások). Csak ezt követően kerülnek sorra a részképességek által kiváltott zavarok: a diszlexia, diszgráfia, diszkalkúlia, valamint a figyelemzavar, amellyel kapcsolatban az a tapasztalat, hogy sok a félinformáció, a félreértés, a helytelen értelmezés a pedagógusok és a jelöltek körében is. Külön témakört alkotnak a fogyatékosságok által kiváltott zavarok, nehézségek: értelmi fogyatékosság, érzékszervi (látás, hallás) fogyatékosság, testi fogyatékosság, beszédfogyatékosság és a beszédfejlődésének zavara, érzelmi-akarati (teljesítmény és alkalmazkodási) sérülés, autizmus, halmozott sérülés. Alkalom nyílik a fogyatékosság, az akadályozottság és a sérülés fogalmának a megkülönböztetésére, aminek tisztázatlansága rossz érzést, esetleg félelmet kelt a mindennapokban, föként amiatt, hogy esetleg bántó kifejezést használunk. Nyilvánvaló, hogy a tárgy féléves időkerete miatt nem csak a témákat, de az SNI tanulókkal kapcsolatos tanórai teendőket sem lehet mélységeiben tárgyalni, ugyanakkor a gondolkodást, az érdeklődést mindenképpen lehet alakítani.

Az „Együttnevelés a közoktatásban” tárgyat választók tisztázzák az együttnevelés és az ezzel kapcsolatba hozható fogalmakat, törvényeket, rendeleteket, illetve a szakszolgálati intézmények feladatait és müködését. Részben a dokumentumokon keresztül tisztázódnak az együttnevelést folytató pedagógusok feladatai, felelössége, a személyi és tárgyi feltételek, részben pedig például iskolai esettanulmány készítésén, érintett pedagógusokkal, tanulókkal való interjú készítésén keresztül. A tárgy, a magyar vonatkozások megismerése mellett igyekszik betekintést adni más országok tanulási zavarral küzdő és az értelmi, testi és érzékszervi fogyatékos tanulóinak az oktatási-nevelési lehetőségeibe is.

Az szabadon választható tárgyak között a tanár szakosok számára választható a „Tanulási- és alkalmazkodási zavarok”, a „Sajátos nevelési igényü gyermekek nevelése” és a „Kisebbségek oktatása” kurzus, amelyek a szükséges alapismereteket adják meg, alakíthatják a hallgatók attitüdjeit, s amelyekre idővel ráépülhetnek majd különféle módszertani képességek, készségek.

A Debreceni Egyetem értelmiségi modulként minden hallgató számára elérhetőként hirdeti meg a „Fogyatékosság vagy speciális szükséglet?”, a „Jelnyelv 1.” és a „Jelnyelv 2." tanegységet, amelyekre minden alkalommal túljelentkezés van. 
A tanárképzésben levelező tagozaton tanulók számára ennél kisebb a kínálat. Jelenleg még csak az általános tárgyakba épül(het)nek be a témát érintő ismeretek, illetve kötelező a „Tanulási nehézségek” címü tanegység.

A tényleges, a tanítás mindennapos gyakorlatához nélkülözhetetlen ismeretek összeállításához és felkínálásához szükséges az igényekről és a nehézségeikről megkérdezni a pedagógusokat (is). A Neveléstudományok Intézete keretei között megalakult Együttnevelés Kutatócsoport az elmúlt évek alatt folyamatosan végzett vizsgálatokat, hogy felderítse a pedagógusoknak az együttneveléssel kapcsolatos félelmeiket, erősségeiket, gyengeségeiket, külön terheiket. A többféle vizsgálat egyike eszközeként egy nemzetközi team által kidolgozott mérési módszert ültettünk át magyar nyelvre. A Sentiments, Attitudes and Concerns about Inclusive Education Scale (SACIE) egy, a pedagógusoknak az inkluzív oktatással kapcsolatos érzelmeit, attitüdjeit és aggodalmaikat mérő vizsgálóeszköz. ${ }^{5}$

A SACIE-vel végzett vizsgálatok a demográfiai és szakmai ismérvek szerinti különbségekre fókuszált, s azt kutatta, hogy a különböző korú, iskolafokon tanító, elözetes ismeretekkel és tapasztalattal rendelkező pedagógusok miképpen vélekednek az SNI gyermekek taníthatóságáról, milyen attitüdök jellemzik őket az integrált neveléssel, inklúzióval kapcsolatban.

A 402 fő pedagógustól nyert adatok azt mutatják, hogy a megkérdezett pedagógusok felének már volt korábban meghatározó kapcsolata vagy élménye valamilyen fogyatékos személlyel. Az SNI-vel kapcsolatos ismereteket csak minden negyedik pedagógus kapott alapképzése ${ }^{6}$ vagy későbbi továbbképzése(i) során. A kurzusok leginkább a pedagógusok saját tudásszintjének megítélésére hatottak pozitívan, de csak keveset változtattak diákjaik taníthatóságával kapcsolatos attitüdjükön. A válaszolók saját, SNI-vel kapcsolatos ismereteiket, illetve a sajátos nevelési igényü diákok taníthatóságát csak gyenge átlagosra értékelték. Utóbbi azt jelzi, hogy kevésbé bíznak bennük, sikerességükben, s részben ezzel fel is ment(het)ik magukat az esetleges sikertelenség okait keresve. Árnyalja a vizsgálat eredményeit, hogy a megkérdezett pedagógusoknak több mint kétharmada vallotta magát tapasztalatlannak vagy kevés tapasztalattal rendelkezőnek az SNI-vel kapcsolatban.

A fenti vizsgálatok eredményei szerint a legkevésbé tapasztaltaknak és a legkevésbé aktívaknak a felső tagozaton, valamint az érettségit adó középiskolákban tanítók látszanak. Az alsó tagozaton tanítók és az érettségit nem adó középiskolák (szakiskolák) pedagógusai találkoznak leggyakrabban az SNI problémájával. Emiatt, s mert úgy tünik, jellemzően ők választottak a témát érintő továbbképzéseket, úgy vallottak magukról, hogy tapasztaltak. Elgondolkodtató, hogy a tapasztalatok és az

\footnotetext{
${ }^{5}$ A kérdőívet megkaptuk az egyik összeállítójától, Chris Forlintól. Az eredmények publikálása folyamatban van.

${ }^{6}$ Két fö óvodapedagógusi, 127 fő tanítóképző főiskolát, 215-en tanárképzőt, 58-an egyetemet végeztek. Az iskolai végzettség elemzésénél a legmagasabb végzettséget vettük figyelembe.
} 
ismeretek magas foka ellenére az alsós tanítók bíztak a legkevésbé a sajátos nevelési igényü diákok taníthatóságában.

Semmiképpen nem tekinthetünk az együttnevelés gyakorlatára úgy, mint egy, csak a sajátos nevelési igényü tanulók érdekeit szolgáló feladatra és gyakorlatra, hiszen miközben a pedagógusok az osztályban tanuló sajátos nevelési igényü gyerekekkel foglalkoznak, várhatóan szakmai haszonra tesznek szert, szakmai tudásuk, módszereik, technikájuk gazdagodik és színesedik. Más szempontok mellett a pedagógusképzés és -továbbképzés során hangsúlyozni kell ezt a pozitív szempontot, hiszen ez hozzájárulhat a pályára kerülő és a pályán lévő tanárok szakmai perspektívájának gazdagodásához. Nem szabad elfeledkezni arról sem, hogy a fogyatékos gyerekek, az érintett diákok véleményét is hasznos megismerni, megérteni, hogy miképpen vélekednek az inklúzióról, hogy milyen érzés számukra inkluzívan nevelkedni.

\section{Irodalom}

Cook, Br. (2002): Inclusive attitudes, strengths, and weaknesses of pre-service general educators enrolled in a curriculum infusion teacher preparation program. Teacher Education and Special Education, No. 3. 262-277.

Fields, B. A. (1993): Inclusive education: Impact on teachers in small rural schools. Education in Rural Australia, No. 3. 11-15.

Forlin, Chr., Loreman, T., Sharma, U., Earle, Ch. (2007): Demographic differences in changing pre-service teachers' attitudes, sentiments and concerns about inclusive education. International Journal of Inclusive Education, No. 2. 195-209.

Goodfellow, J. (1990): Personal preparation for successful integration of young children with special education needs - a case study. Australian Journal of Early Childhood, No. 15. 9-14.

Kowalski, E. (1995): The infusion approach to teacher development. Journal of Physical Education, Recreation, and Dance, No. 4. 49-54.

Pető Ildikó, Nagy Zita Éva (2004a): Az észak-alföldi régió általános iskolái - a befogadó nevelés szempontjából. Iskolakultúra, 4. sz. 51-60.

Pető Ildikó, Nagy Zita Éva (2004b): Helyzetkép a befogadó nevelésről az észak-alföldi régió iskoláiban. Új Pedagógiai Szemle, 4-5. sz. 172-190.

Sharma, U., Forlin, C., Loreman, T. (2008): Impact of training on pre-service teachers' attitudes and concerns about inclusive education and sentiments about persons with disabilities. Disability \& Society, No. 7. 773-785.

1062/2007. (VIII. 7.) Korm. határozat az új Országos Fogyatékosügyi Program végrehajtásának 2007-2010. évekre vonatkozó középtávú intézkedési tervéröl

www.szmm.gov.hu/openlink.php?linkID=1263 